for particular categories of students, but all should share teaching and laboratory facilities and be admitted to membership of the Students' Union.

\title{
Recherche scientifique en Madagascar
}

L'INstrTur de Recherche Scientifique de Madagascar, rattaché à l'Office de la Recherche Scientifique Outre-Mer, fut créé en 1946 par le professeur Millot, du Muséum National d'Histoire Naturelle de Paris, qui en conserve toujours la direction, assisté de son adjoint le Dr. Pauliau. Il a été édifié au pied des escarpements de Tananarive sur la pente dominant le vallon de Tsimbazaza.

Dans le bâtiment principal sont réunis les bureaux, la bibliothèqué, les laboratoires de biologie, de botanique, d'ethnologie, de chimie végétale et de parasitologie. Le sous-sol est organisé en salle de conférences. L'ancien jardin zoologique et botanique a été annexé à l'Institut. La section d'ethnographie est la dernière créée. Des fouilles ont été effectuées dans les nécropoles islamiques du nord-est et, d'autre part, l'ethnologue procède actuellement à une étude sociologique de la population Tsimihety. Des collections d'objets sont recueillies, destinées à un musée d'ethnographie dont la construction est prochaine.

\section{'Centre Africain' de l'Université Franco-Belge de New-York}

LE 'Centre Africain' a clôturé sa première année d'activité. Pendant cette période le professeur Jean Maynard a dirigé un séminaire en anglais sur l'Afrique contemporaine, suivi par 17 étudiants, et le professeur Jean Comhaire a donné un cours en français sur l'histoire de l'Afrique, suivi par 2 I élèves. Diverses personnalités ayant une grande expérience des questions africaines ont participé à ces travaux, notamment M. Goiran, ancien ministre de France en Afrique du Sud, M. Sieck, ancien vice-consul de Suisse à Dakar, et le Père de Pauw, ancien missionnaire franciscain au Katanga.

\section{Union Internationale pour la Protection de la Nature}

A PAMPHLET prepared with the assistance of UNESCO and distributed by IFAN, Dakar, sets forth the aims of the U.I.P.N., which was founded in 1948 for the purpose of securing the collaboration of governments, administrations, international and national institutions in the protection of the land, of wild fauna and birds, and of plants. Its particular subjects of study are the use or abuse of natural resources, the dangers of deforestation, the extermination of natural species by unregulated hunting and fishing, the destruction of indigenous vegetation and the introduction of unsuitable exotic species. Meetings of the Union were held in 1950 at Brussels, in 1952 at Caracas in Venezuela, as a result of which recommendations have been made to the governments of more than 25 countries. A volume of 538 pages entitled Etat de la Protection de la Nature dans le monde en 1950 was published under the auspices of the Union, a Bulletin d'information, in French and English, is published every two months by the Secretariat, and toneoed pamphlets are issued periodically by IFAN, Dakar; a commission on Public Information has been established in Washington, D.C. The Secretary General of the Union is M. Harroy, 42 Rue Montoyer, Brussels, Belgium. 